\title{
PENGEMBANGAN MODEL LATIHAN SIRKUIT PASING BAWAH T-DESAIN (SPBT-DESAIN) BOLA VOLI SEBAGAI BENTUK AKTIVITAS BELAJAR SISWA DALAM PEMBELAJARAN PJOK UNTUK TINGKAT SEKOLAH MENENGAH
}

\author{
Yohanes Bayo Ola Tapo \\ Dosen PJKR STKIP Citra Bakti \\ email: yohanesbayoolatapo@gmail.com
}

\begin{abstract}
Abstrak
Penelitian ini merupakan penelitian pengembangan(research and development) level 3 menurut Borg and Gall dalam Sugiyono (2016) dan merupakan penelitian multi years yang dilaksanakan dalam dua tahap penelitian yaitu; Penelitian tahap 1; berfokus pada penelitian dan pengembangan produk sampai pada uji kelayakan penggunaan, dan Penelitian tahap 2; berfokus pada penelitian uji efektivitas produk pada aktivitas dan hasil belajar siswa. Tujuan penelitian ini adalah: (a) Mengembangkan model latihan Sirkuit Pasing Bawah T-Desain (SPBTDesain) Bola Voli yang dapat digunakan sebagai bentuk aktivitas belajar siswa dalam pembelajaran PJOK untuk tingkat sekolah menengah, (b) Menguji kelayakan penggunaan produk yang dikembangkan dalam hal pelaksanaan pembelajarannya. Subyek dalam penelitian ini adalah siswadari beberapa sekolah menengah yang ada di Kecamatan Golewa dan Bajawa.Instrumen dalam penelitian ini menggunakan instrument validasi ahli dan instrument uji kelayakan penggunaan produk yang diberikan pada 3 (tiga)orang ahli yaitu: 1 orang dosen, 1 orang pengawas PJOK dan 1 guru PJOK tempat pelaksanaan penelitian. Hasil penelitian berupa produk akhir pengembangan disusun dalam sebuah buku pedoman yang dilengkapi dengan video aktivitas latihan dan diberi judul: "Buku Panduan Model Latihan Sirkuit Pasing Bawah T-Desain (SPBT-Desain) Bola Voli", sedangkan hasil validasi dan uji kelayakan penggunaan produkdianalisis menggunakan teknik analisis deskriptif kuantitatif, dan diperoleh simpulan penelitian bahwa:berdasarkan hasil penilaian dari para ahli dalam uji kelayakan penggunaan produk pada uji skala kecil dan uji skala besar menunjukan bahwa: model latihan Sirkuit Pasing Bawah T-Desain (SPBTDesain) Bola Voli "Baik dan Layak" digunakan sebagai bentuk aktivitas belajar siswa dalam pembelajaran PJOK materi permainan bola besar (bola Voli) untuk tingkat sekolah menengah.
\end{abstract}

Kata Kunci: Pengembangan, model latihan Sirkuit, pasing bawah bola voli, aktivitas belajar sisiwa.

\begin{abstract}
This research is a level 3 research and development according to Borg and Gall in Sugiyono (2016) and is a multi-year study carried out in two phases of research; Phase 1; focusing on development product research to usability testing, and Phase 2; research focuses on product effectiveness testing on student activities and learning outcomes. The objectives of this study are: (a) Developing volleyball forearm pass circuit training model T-Desain (SPBTDesain) to use as a form of student learning activities in PJOK learning for secondary schools, (b) Test the feasibility of using products that are developed in terms of the implementation of learning. The subjects in this
\end{abstract}


study were students from several secondary schools in the Golewa and Bajawa Districts. The instrument in this study uses expert validation instrument and product feasibility test instrument given to 3 (three) experts, namely: 1 lecturer, 1 PJOK supervisor and 1 PJOK teacher where the research is conducted. The results of the final product development research are arranged in a guidebook that is equipped with a video of training activities, with the title: "Buku Panduan Model Latihan Sirkuit Pasing Bawah $T$-Desain (SPBT-Desain) Bola Voli", while of the results of validation and feasibility tests for product use were analyzed using quantitative descriptive analysis techniques, and research conclusions: based on the results of the assessment of the experts in the feasibility of using the product on a small scale test and large scale test shows that: Volleyball forearm pass circuit training model T-Desain (SPBT-Desain) "Good and Feasible" to be used as a form of student learning activities in PJOK learning to be used as a form of student learning activities in PJOK Volleyball lessons for secondary school level.

Keywords:Development, circuit training model, volleyball forearmpass, student learning activities.

\section{PENDAHULUAN}

Undang-Undang nomor 20 Tahun 2003, menjelaskan bahwa pendidikan nasional berfungsi mengembangkan kemampuan dan membentuk watak serta peradaban bangsa yang bermartabat dalam rangka mencerdaskan kehidupan bangsa, bertujuan untuk berkembangnya potensi peserta didik agar menjadi manusia yang beriman dan bertakwa kepada Tuhan Yang Maha Esa, berakhlak mulia, sehat, berilmu, cakap, kreatif, mandiri, dan menjadi warga negara yang demokratis serta bertanggung jawab (UndangUndang RI: 2003).

Dalam rangka mencapai tujuan pendidikan nasional tersebut upaya dan usaha sadar dilaksanakan lembaga pendidikan dengan berbagai implementasi mata pelajaran sebagai proses pembelajaran siswa yang salah satunya adalah mata pelajaran Pendidikan Jasmani, Olahraga dan
Kesehatan (PJOK). Esensi dasar dari PJOK seperti yang disebutkan pada SK Menpora nomor 053A/MENPORA/1994, menjelaskan bahwa: Pendidikan jasmani merupakan suatu proses pendidikan yang dilakukan secara sadar dan sistematis melalui berbagai kegiatan jasmani dalam rangka memperoleh kemampuan dan keterampilan jasmani, pertumbuhan fisik, kecerdasan dan pembentukan watak (Menpora: 1994). Pengertian ini menggandung beberapa unsur penting yang perlu diperhatikan, yaitu: Pendidikan jasmani dilakukan secara sadar dan sistematis, kegiatan pembelajaran dilakukan dalam bentuk berbagai kegiatan jasmani, dan tujuan dasar dari pembelajaran penjas adalah memperoleh keterampilan jasmani dan berbagai kemampuan dasar anak, sedangkan menurut Depdiknas (2006), menegaskan bahwa pendidikan jasmani adalah 
suatu proses pembelajaran melalui aktivitas jasmani yang didesain untuk meningkatkan kebugaran jasmani, mengembangkan keterampilan motorik, pengetahuan dan perilaku hidup sehat dan aktif, sikap sportif, dan kecerdasan emosi untuk meningkatkan pertumbuhan dan perkembangan seluruh ranah, jasmani, psikomotor, kognitif, dan afektif setiap siswa

Berdasarkan penjelasan ini, maka dapat disimpulkan secara umum pengertian Pendidikan Jasmani, Olahraga dan Kesehatan (PJOK) adalah: "Proses pembelajaran melalui aktivitas jasmani yang dilakukan secara sadar dan didesain secara sistematis untuk meningkatkan kebugaran, pertumbuhan dan perkembangan seluruh ranah atau aspek, yang meliputi: aspek jasmani, psikomotor, kognitif, dan afektif setiap peserta didik (siswa)". Simpulan pengertian ini memberikan dua makna dasar dari PJOK, yaitu: (1). Pendidikan untuk jasmani; proses pembelajaran sebagai sarana yang berfokus pada pengembangan dan keterampilan fisik berbagai aktivitas jasmani dan keterampilan cabang olahraga. dan (2). Pendidikan melalui jasmani; proses pembelajaran dengan memanfaatkan berbagai aktivitas jasmani dan keterampilan gerak cabang olahraga sebagai sarana belajar guna mencapai Tujuan Pendidikan Nasional.

$\begin{array}{cr}\text { Pembelajaran } & \text { PJOK } \\ \text { guna }\end{array}$

memungkinkan seluruh peserta didik memiliki kesempatan yang cukup untuk dapat aktif bergerak serta mempelajari berbagai keterampilan jasmani dan kecabangan olahraga dengan harapan agar peserta didik dapat mengembangkan kompetensi berbagai aspek yang dibutuhkan mulai dari aspek jasmani, aspek kognitif (pengetahuan), aspek psikomotor (keterampilan) dan aspek afektif (sikap dan mental). Hal ini kemudian menuntut pendidik untuk selalu dapat menyelenggarakan pembelajaran PJOK yang baik, efektif, efisien, bervariatif dan menyenangkan, sehingga pelaksanaan pembelajaran PJOK yang bermutu haruslah diperhatikan mulai dari proses dan hasil yang dapat ditinjau dari aktivitas dan hasil belajar siswa.

Implementasi pembelajaran PJOK dilaksanakan dengan materimateri pembelajaran yang termuat dalam pemenuhan Standar Isi dan Standar Kompetensi yang termuat dalam kurikulum. Menurut Permendikbud (Nomor 21 Tahun 2016), muatan ruang lingkup materi PJOK pada jenjang pendidikan SMP dan SMA salah satunya adalah aktivitas fisik dan berbagai gerakan dasar olahraga permainan bola besar, yang terdiri dari cabang olahraga sepakbola, bola voli dan bola basket yang merupakan materi kompetensi isi yang pertama pada semua jenjang pendidikan. Materi teknik dasar permainan bola voli adalah salah satu materi pembelajaran PJOK 
yang paling banyak dan menjadi salah satu materi yang selalu diberikan pada setiap semester dan kelas. Materi pembelajaran permainan bola voli dalam pembelajaran PJOK seperti yang termuat dalam buku guru dan buku siswa, mempelajari esensi dasar permainan bola voli serta berbagai keterampilan teknik dasarnya yang berorientasi pada indikator hasil belajar siswa dalam menguasai kemampuan dasar dan keterampilan teknik dasar permainan bola voli secara bertahap dan berjenjang.

Fédération Internationale de Volleyball (FIVB) dalam Official Volleyball Rules 2017-2020 (2016: 9) menyebutkan bahwa Bola voli adalah salah satu olahraga kompetitif dan rekreasi paling sukses dan populer di dunia. Permainan yang cepat (fast), menyenangkan (exciting), aksi yang meledak (explosive) dan terdiri dari beberapa elemen yang interaktif yang menjadikannya unik di antara permainan reli (rally) lainnya. FIVB (2016: 7) menjelaskan esensi dari bahwa bola voli adalah olahraga yang dimainkan oleh dua tim di lapangan bermain yang dibagi atau dibatasi dengan jaring (net). Tujuan permainan adalah memberikan bola melewati jaring (net) untuk menempatkannya di lapangan lawan, dan mencegah upaya yang sama dari lawan.

Berdasarkan penjelasan menurut FIVB ini, esensi permainan bola voli secara umum dapat dirangkum bahwa pengertian permainan bola voli adalah "Olahraga permainan bola besar yang dimainkan pada area permainan (lapangan) khusus oleh dua regu dengan masing-masing regu terdiri dari enam pemain, yang memainkan bola dengan ketentuan khusus untuk menyeberangi bola melewati jaring (net)". Ditinjau dari pengertian permainan bola voli ini, maka hakikat atau esensi tujuan dasar permainan bola voli, adalah memainkan bola untuk menyeberangi atau melewatkan bola dari bagian atas jaring (net) dengan teknik dan ketentuan khusus dalam rangka: (a) menempatkan bola agar menyentuh permukaan lapangan pada daerah permainan lawan, dan (b) mempertahankan bola agar tidak menyentuh permukaan lapangan pada daerah permainan sendiri, sehingga menjadi dua bentuk kegiatan atau aktivitas pokok selama permainan dengan ketentuan-ketentuan khusus yang membatasi cara pemain dalam memainkan bola dengan berbagai keterampilan gerak teknik dasar, yang selanjutnya dapat diklasifikasikan menjadi dua kelompok bentuk teknik dasar, yaitu kelompok teknik dasar untuk menyerang dan kelompok teknik dasar untuk bertahan dalam penerapan strategi permainan bola voli

Lenberg, K (2006: iv) menyebutkan bahwa bola voli memiliki enam keterampilan yang harus dikuasi yaitu serving (keterampilan melakukan servis), 


\begin{tabular}{lrlrl}
\hline serve receiving & (keterampilan & serve receiving & (keterampilan \\
menerima servis), setting & menerima servis), (2) teknik dasar \\
(mengumpan), & attacking & pasing atas yang juga dikenal \\
(keterampilan & menyerang), & dengan istilah & setting \\
blocking (keterampilan melakukan & (mengumpan). & \\
blok), dandigging (keterampilan & \multicolumn{2}{c}{ Secara khusus teknik dasar }
\end{tabular}
menahan bola). Berdasarkan penjelasan ini, maka dapat disimpulkan bahwa teknik dasar permainan bola voli terdiri dari teknik dasar servis, pasing, smash dan blok yang merupakan salah satu syarat mutlak yang harus dikuasai oleh setiap pemain bola voli. Lebih lanjut dijelaskan bahwa serve receiving (keterampilan menerima servis) adalah komponen terpenting dalam keseluruhan skema atau strategi menyerang (offensive) sebuah tim bola voli, jika sebuah tim tidak dapat menerima servis tim lawan dan bertransisi menjadi serangan yang efektif, kemungkinan tim akan mengalami kekalahan. serve receiving (menerima servis) dan pass (mengoper bola) dikatakan sama karena tugas utama penerima servis adalah mengoper bola ke pemain lain(Lenberg, $\mathrm{K}$, 2006: 20).

Dalam permainan bola voli penguasaan teknik dasar pasing merupakan salah satu syarat mutlak yang harus dimiliki oleh pemain bola voli karena merupakan satu-satunya teknik dasar memukul bola dengan tujuan untuk mengoper dan/atau mengumpan.Teknik dasar pasing dibedakan menjadi dua teknik dasar, yaitu: (1) teknik dasar pasing bawah atau yang juga dikenal dengan istilah keterampilan pasing bawah adalah:"Teknik dasar memukul bola dalam permainan bola voli dengan menggunakan dua lengan tangan dengan posisi bola yang lebih rendah dari dada, dengan tujuan dasar adalah menerima bola dari hasil servis lawan untuk kemudian mengoper bola tersebut kepada teman untuk dimainkan lagi selanjutnya", sehingga perlu diperhatikan bahwa hasil dari pasing bawah harus tepat, lembut dan tidak menyusahkan teman seregu.

Lenberg, K (2006: 21-26), menjelaskan pelaksanaan teknik dasar pasing bawah, terdiri dari beberapa tahapan, yaitu: Passing Process: tahap persiapan, pastikan memiliki alas (tumpuan) kaki yang lebar (kedua kaki sejajar sedikit lebih lebar dari bahu) atau dengan posisi salah satu kaki sedikit lebih ke depan, lutut sedikit ditekuk dan jari-jari kaki menghadap ke depan dengan posisi telapak kaki sedikit masuk ke arah dalam, tidak ke luar, berat badan ditumpu pada kedua kaki, serta posisi punggung dan bahu harus membentuk sudut 45 derajat dari lantai, posisi lengan pada tahap ini harus direntangkan ke depan dan sejajar dengan kaki (paha) bagian atas, tangan tidak digenggam terlebih dahulu serta telapak tangan menghadap ke 
atas, tubuh bagian atas harus rileks dan siap untuk menerima servis (melakukan pasing), (2) Execution Process: tahap pelaksanaan, pemain harus dapat memprediksi arah bola secepat mungkin, kemudian awali dengan langkah ke arah datangnya bola tidak dengan melompat tetapi dengan langka dan diistilakan dengan "step and plant" (mengambil langkah ke arah bola kemudian membentuk sikap persiapan dengan menempatkan kedua kaki dalam posisi sedikit dibuka selebar bahu, kedua kaki dan posisi badan (bahu dan pinggul) harus tepat berada di belakang menghadap ke arah bola, bersamaan dengan membentuk posisi kaki dan badan, kedua tangan disatukan dengan teknik genggaman jari tangan dengan posisi kedua lengan tangan lurus dan posisi siku lurus dikunci, kedua bahu sedikit diangkat ke depan dan tetap menjaga posisi kedua lengan yang membentuk bidang pantul yang kuat. Pemain harus tetap dapat menjaga bentuk dan posisi kedua lengan walaupun kaki dan badan bergerak, pemain harus mampu melihat dan mengawasi bola yang datang dan menempatkan posisi lengan tangan sejajar dengan bola, pada saat bola akan menyentuh kedua lengan tangan, pemain harus terlebih dahulu mengayunkan kedua lengan tangan ke arah bola dengan mengayunkan atau mengangkat kedua bahu ke atas dengan gerakan yang lembut.

\begin{abstract}
Berdasarkan penjelasan ini, secara lebih terperinci keterampilan gerak teknik dasar pasing bawah dapat disimpulkan dalam beberapa bagian teknik dasar pasing bawah, sebagai berikut.
\end{abstract}

1) Sikap Awal (Tahap Persiapan), adalah bentuk gerakan dasar bersiap dalam melakukan teknik dasar pasing bawah, rangkaian gerakannya adalah; (a) bergerak ke arah datangnya bola dengan melangkah (step), tempatkan badan pada posisi yang sejajar (lurus) tepat di belakang bola (pada saat ini kedua lengan tangan jangan dulu digenggam), (b) buka kedua kaki sejajar sedikit lebih lebar dari bahu (dapat juga dilakukan dengan posisi salah satu kaki berada di depan) dan jari-jari kaki menghadap ke depan sedikit dimasukan ke arah dalam, serta kedua lutut ditekuk rendah dan posisi badan rileks agak condong ke depan, (c) posisikan badan jongkok ke depan yang dilakukan dengan cara menekukan kedua lutut bukan membungkuk, (d) kedua tangan disatukan dengan salah satu teknik genggaman jari tangan dengan posisi lengan tangan diluruskan atau direntangkan ke depan sejajar dengan kaki (paha) bagian atas dan lengan dikeraskan atau ditegangkan, (e) kedua mata memandang ke arah 
datangnya bola dan ke arah mana bola akan di pasing.

2) Saat Pelaksanaan (Tahap Melakukan Pasing), adalah bentuk melakukan gerakan memukul bola dengan menggunakan tangan (saat dimana perkenaan bola dengan tangan), rangkaian keterampilan geraknya adalah;

(a) saat bola datang usahakan badan serileks mungkin dan mata memperhatikan arah datangnya bola, (b) saat bola mendekat, ayunkan terlebih dahulu tangan sejajar ke atas dengan berporos pada sendi bahu dengan tambahan gerakan mengangkat kedua bahu ke atas dengan gerakan yang lembut dan posisi siku tidak ditekuk sama sekali, usahakan perkenaan bola dengan tangan tepat seimbang pada kedua lengan tangan bagian dalam, (c) saat memukul bola, ikuti dengan gerakan sedikit meluruskan lutut yang ditekuk, serta ditambah dengan sedikit gerakan lecutan pergelangan dan telapak kaki, (d) keras lembutnya ayunan tangan disesuaikan dengan sasaran yang akan dituju, usahakan bola berjalan secara parabola ke depan atas menuju sasaran, (e) lengan tangan diayunkan terus sampai tangan sejajar dengan bagian dada dan dagu, sebagai bentuk gerakan lanjutan agar jalannya bola lebih terarah.
3) Sikap Akhir (Tahap Lanjutan), adalah sikap pada saat setelah melakukan gerakan memukul bola, gerakan pada sikap akhir cukup penting dilakukan karena gerakan pada sikap akhir yang baik dan benar memungkinkan kita untuk dapat melakukan gerakan selanjutnya, gerakan sikap akhir dapat dilakukan dengan bentuk gerakan sebagai berikut: setelah memukul bola (sentuhan lengan tangan dengan bola) gerakan dilanjutkan dengan terus mengamati secara saksama arah jalannya bola dan kemudian kembali pada sikap awal atau melakukan tahap persiapan untuk gerakan atau teknik dasar lainnya atau selanjutnya.

Menurut M. Sajoto (1995:83) latihan sirkuit adalah suatu program latihan yang terdiri dari beberapa stasiun dan di setiap stasiun seorang atlet melakukan jenis latihan yang telah ditentukan. Satu sirkuit latihan dikatakan selesai, bila seorang atlet telah menyelesaikan latihan di semua stasiun sesuai dengan dosis yang telah ditetapkan.

Brett Klika dan Chris Jordan dalam artikelnya menjelaskan bahwa latihan dengan metode circuit training dilakukan dalam 9 sampai 12 protokol pos latihan, dimana peserta melakukan latihan dengan intensitas sedang dalam sejumlah repetisi atau waktu tertentu dalam satu pos dan pindah ke pos latihan berikutnya dengan 
waktu istirahat yang singkat (Klika, B \& Jordan, C: 2013).

Berdasarkan pengertian ini dapat kita simpulkan bahwa esensi dasar dari model latihan circuit training adalah model latihan yang dilakukan dalam pos-pos latihan yang terdiri dari bentuk latihan yang berbeda-beda yang harus dilalui atau dilakukan peserta latihan dengan ketentuan ulangan atau waktu latihan tertentu dari pos pertama ke pos berikutnya sampai pos yang terakhir secara kontinyu dengan durasi waktu istirahat yang sangat singkat antar pos latihan.

Lehnert, $M$, Stastny, $P$,...etc (2015: 561) menjelaskan pendapat (Siff, 2003) bahwa metode latihan yang sering digunakan untuk mengembangkan atau mempertahankan kemampuan atau kebugaran jasmani yang berhubungan dengan kesehatan adalah pelatihan circuit training, karena memungkinkan untuk menggunakan berbagai variasi program latihan seperti program latihan dengan perubahan secara berurutan untuk latihan tubuh bagian atas dan bawah, latihan kelompok agonis dan antagonis, atau untuk bentuk latihan yang kompleks dan spesifik.

Berdasarkan pembahasan, dalam penelitian ini bentuk latihan circuit trainingyang digunakan sebagai model dasar dari model latihan yang dikembangkan adalah pola dan bentuk latihannya, sehingga penekanan ketentuan model latihan yang dikembangkan adalah sebagai berikut: (1) pola latihan dilakukan dalam pos-pos latihan sebanyak 8 pos, (2) setiap pos latihan mencakup bentukbentuk latihan pasing bawah bola voli dengan bentuk latihan yang berbeda-beda, (3) bentuk latihan dari pos pertama sampai pos terakhir dibuat dengan urutan latihan mulai dari yang paling sederhana sampai yang paling kompleks, (4) setiap pos memiliki ketentuan ulangan dan waktu latihan yang berbeda-beda, (5) durasi waktu istirahat (interval) antar pos dibuat sesingkat mungkin antara 10 sampai 15 detik.

Penelitian dan pengembangan dibuat dimaksudkan untuk menghadirkan suatu model aktivitas belajar siswa pada kegiatan inti dalam pembelajaran PJOK di sekolah menengah, hal ini dilakuka guna menghadirkan sebuah solusi untuk beberapa kendala atau masalah yang sering ditemui dalam pelaksanaan pembelajaran PJOK materi pasing bawah bola voli terutama pada kegiatan inti, diantaranya: variasi metode, model dan variasi latihan pasing bawah yang kurang bervariasi serta kurangnya saranaprasarana latihan, hal ini kemudian membuat pembelajaran PJOK menjadi tidak menyenangkan dan berdampak pada rendahnya aktivitas belajar siswa, sehingga secara langsung berdampak pula pada hasil belajar siswa yang tidak sesuai dengan tujuan, ketentuan dan harapan, untuk itu diperlukan sebuah upaya konkrit untuk mengemas pembelajaran menjadi lebih bervariasi dan menyenangkan dengan sebuah 
model atau metode dalam pembelajaran secara khusus pada aktivitas belajar siswa, sehingga pendidik (guru) dapat menyelenggarakan pembelajaran PJOK yang baik, efektif, efisien, bervariatif dan menyenangkan terutama dalam pembelajaran pasing bawah bola voli. Hal ini diharapakan agar pendidik memiliki alternatif dalam mengemas pembelajaran dengan berbagai metode, model, variasi dan pola belajar yang benar-benar baik agar siswa dapat lebih termotivasi dalam mempelajari materi pasing bawah bola voli.

Menerapkan pola latihan circuit training dalam pos-pos dengan bentuk latihan yang berbeda-beda akan dipakai oleh peneliti sebagai sebuah dasar pengembangan metode latihan sebagai aktivitas belajar siswa dalam pembelajaran penjas pada materi teknik dasar pasing bawah, dengan memodifikasi kemudian mengembangkan bentuk-bentuk latihan dasar teknik pasing bawah ke dalam bentuk pos-pos latihan, sehingga beberapa siswa dapat terlibat secara bersamaan dalam melaksanakan aktivitas belajar dan dapat mempelajari teknik dasar pasing bawah bola voli secara lebih baik karena bentuk teknik dasar pasing bawah akan dipecah kedalam pos-pos dengan bentuk latihan bagian per bagian sampai secara keseluruhan. Hal ini akan memberikan dampak yang efektif dalam pembelajaran PJOK materi pasing bawah, diantaranya: guru memiliki alternatif metode kegiatan inti dalam pembelajaran, siswa mendapat kesempatan bergerak yang cukup namun tidak membosankan karena aktivitas belajar dilaksanakan di dalam pospos yang memiliki bentuk latihan yang berbeda-beda, keterampilan siswa akan maksimal karena siswa dikondisikan untuk mempelajari keterampilan gerak teknik dasar pasing bawah secara bagian per bagian sebelum berlatih secara keseluruhan.

\section{METODE PENELITIAN}

Model pengembangan yang digunakan dalam penelitian ini adalah model penelitian dan pengembangan (research and development) level 3 menurut Borg and Gall dalam Sugiyono (2016). Penelitian dilakukan dengan merancang prosedur dan produk pengembangan model latihan sirkuit pasing bawah bola voli sebagai aktivitas belajar siswa, kemudian secara sistematis divalidasi,diuji di lapangan, dan disempurnakan sampai memenuhi kriteria kelayakan penggunaan produk.

Prosedur pengembangan yang dilakukan dalam penelitian ini diadopsi dari prosedur penelitian dan pengembangan (R\&D) level 3 yang dimodifikasi oleh Tapo (2017)menjadi 10 langkah penelitian, yaitu: (1) penelitian produk yang telah ada (studi literatur dan penelitian lapangan), (2) perencanaan pengembangan produk, (3) pengujian internal desain (validasi ahli), (4) revisi desain produk awal, (5) uji coba 
terbatas (skala kecil), (6) revisi produk 1, (7) uji coba lapangan utama (skala besar), (8) revisi produk 2, dan (9) produk akhir.

Desain uji coba produk dalam penelitian ini, menggunakan 3 (tiga) bentuk uji coba produk, yaitu: (a)Uji internal desain (validasi ahli) draf produk, dibuat untuk memvalidasi kelayakan draf produk oleh 3 orang ahli, yang terdiri dari: 2 orang ahli dari unsur akademisi (dosen dan pengawas PJOK) dan 1 orang ahli praktisi pembelajaran (guru PJOK) menggunakan angket sakala nilai validasi draf produk awal, setelah dikatakan valid oleh ketiga ahli, maka selanjutnya draf produk menjadi produk awal yang siap untuk diuji coba kelayakan penggunaan produk dalam pembelajaran PJOK materi pasing bawah bola voli, (b) Uji coba terbatas (skala kecil) penggunaan produk awal, dibuat untuk menguji kelayakan penggunaan produk awal dengan jumlah subjek yang kecil. Evaluasi dilakukan oleh para ahli menggunakan lembar observasisaat pelaksanaan pembelajaran, serta dilakukan dokumentasi dalam bentuk foto untuk digunakan sebagai dokumen dan data pendukung penelitian, dan (c)Uji coba lapangan utama (skala besar) penggunaan produk awal, dibuat untuk menguji kelayakan penggunaan produk awal dengan jumlah subjek yang lebih besar. Evaluasi dilakukan oleh para ahli menggunakan lembar observasisaat pelaksanaan pembelajaran, serta dilakukan dokumentasi dalam bentuk foto untuk digunakan sebagai dokumen dan data pendukung penelitian.

Dalam penelitian ini, digunakan tiga bentuk instrumen, yaitu: (a) Instrumen Validasi Draf Produk, menggunakan instrumen angket skala nilai uji material untuk menilai kesesuaian draf produk sebagai produk yang layak digunakan dalam pembelajaran PJOK materi teknik dasar pasing bawah bola voli. (b). Instrumen Uji Coba Kelayakan Penggunaan Produk Awal, menggunakan instrumen lembar observasi untuk mengamati dan menilai kelayakan produk awal digunakan dalam pembelajaran PJOK materi teknik dasar pasing bawah bola voli, dan (c) Instrumen dalam bentuk dokumentasi, semua aktivitas dalam uji coba didokumentasikan dalam bentuk foto yang digunakan oleh peneliti sebagaidokumen pendukung dalam merevisi dan menyempurnakan produk.

Teknik analisis data dalam penelitian pengembangan ini menggunakan dua bentuk teknik analisis data, yaitu analisis data deskriptif kualitatif pada hasil observasi, angket, komentar masukan atau saran dari para ahli dengan data yang bersifat teks dan analisis data deskriptif kuantitatif digunakan pada data hasil penilaian ahli dengan data yang bersifat angka atau nilai dari skala penilaian, yang akan dianalisis menggunakan norma kategorisasi sesuai dengan ketentuan Saifuddin Azwar (2012: 149), sebagai berikut 


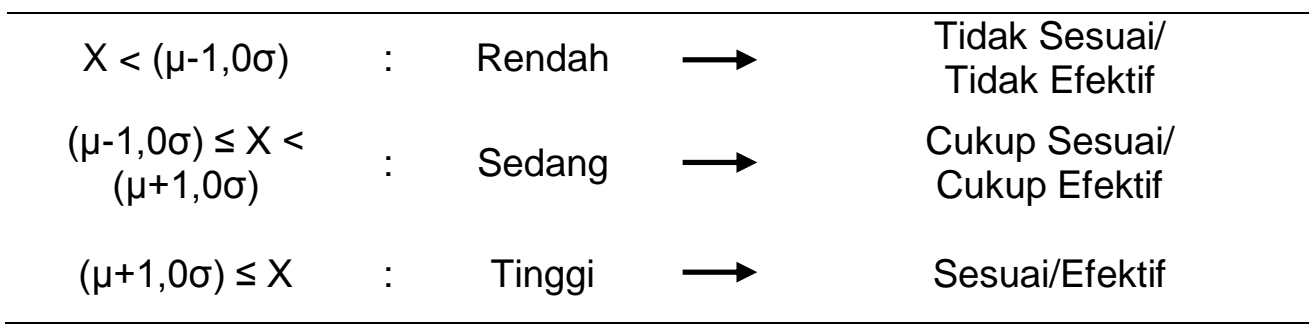

Keseluruhan bentuk teknik analisis data digunakan dalam kepentingan penarikan kesimpulan sebagai saran atau masukan ahli untuk dilakukan revisi produk dan rujukan dalam menarik kesimpulan akhir pengembangan produk dan simpulan penelitian. Produk pengembangan dikatakan Baik dan Layak jika $100 \%$ (3 orang) ahli memberikan penilaian pada rentang perhitungan: $(\mu+1,0 \sigma) \leq X$ yang berada pada Kategori Tinggi dan Sesuai/Efektif.

\section{HASIL PENELITIAN DAN PEMBAHASAN}

Hasil pengumpulan data pada tiga uji coba produk oleh tiga orang ahli sesuai dengan instrument masing-masing tahap uji coba, kemudian disesuaikan dengan norma kategorisasi kesesuaiandraf produk dan kelayakan produk awal seperti pada Tabel. 1, untuk kemudian ditarik kesimpulan dari hasil uji coba dan menentukan apakah produk baik dan layak

Tabel 1. Perhitungan Norma Kategorisasi

\begin{tabular}{ccc}
\hline Formula & Interval & Kategori \\
\hline$X<(\mu-1,0 \sigma)$ & $X<23$ & Kurang Sesuai \\
$(\mu-1,0 \sigma) \leq X<$ & $23 \leq X<37$ & Cukup Sesuai \\
$(\mu+1,0 \sigma)$ & $37 \leq X$ & Sesuai \\
$(\mu+1,0 \sigma) \leq X$ & & \\
\hline
\end{tabular}

Berdasarkan hasil penilaian dari tiga uji coba produk, adapun hasil penilaianadalah sebagai berikut.

1. Hasil uji coba internal desain

(validasi ahli) draf produk.
Draf produk terlebih dahulu divalidasi oleh para ahli, dengan hasil pada Tabel. 2

Tabel 2. Data Hasil Validasi Ahli Kesesuaian Draf Produk

\begin{tabular}{cccccccccccc}
\hline \multicolumn{1}{c}{ Kod } & 1 & 2 & 3 & 4 & 5 & 6 & 7 & 8 & 9 & 1 & \\
$e$ & \multicolumn{1}{c}{ Hasil Penilaian Ahli } \\
Ahli & \multicolumn{1}{c}{ (Angket Skala Nilai) } \\
\hline A1 & 5 & 5 & 5 & 4 & 4 & 4 & 3 & 4 & 5 & 4 & \\
A2 & 5 & 5 & 5 & 4 & 4 & 4 & 3 & 4 & 5 & 4 & \\
A3 & 5 & 5 & 5 & 4 & 4 & 4 & 3 & 4 & 5 & 4 & 43 \\
\hline
\end{tabular}




\section{Keterangan:}
A1 : Ahli 1 (Dosen)
A2 : Ahli 2 (Pengawas PJOK)
A3 : Ahli 3 (Guru PJOK)

Berdasarkan norma kategorisasi,distribusi frekuensi nilai validasi para ahli pada Tabel. 3.

Tabel 3. Distribusi Frekuensi Penilaian Kesesuaian Ahli Draf Produk

\begin{tabular}{ccccc}
\hline Kategori & $\begin{array}{c}\text { Kurang } \\
\text { Sesuai }\end{array}$ & $\begin{array}{c}\text { Cukup } \\
\text { Sesuai }\end{array}$ & Sesuai & Jumlah \\
\hline $\mathrm{F}$ & 0 & 0 & 3 & 3 \\
$\%$ & 0 & 0 & $100 \%$ & $100 \%$ \\
\hline
\end{tabular}

Berdasarkan Tabel. 3, ketiga ahli memberikan nilai validasi draf produk dengan rata-rata $(43,0)$ dan berada pada interval $(37 \leq X) k a t e g o r i ~(s e s u a i)$, sehingga ketiga ahli (100\%) menilai bahwa draf produk pengembangan berupa model latihan Sirkuit Pasing Bawah T-Desain (SPBT-Desain) bola voli "Baik danLAYAK"untuk dilanjutkan ke tahap uji coba kelayakan penggunaan produk awal pada uji coba terbatas (skala kecil),
2. Hasil uji coba terbatas (skala kecil) penggunaan produk awal

Setelah draf produk tervalidasi secara uji materi oleh ketiga ahli, dilanjutkan dengan uji coba terbatas (skala kecil) penggunaan produk awal, dengan melibatkan 1 kelas sekolah menengah pertama dan 1 kelas sekolah menengah atas, dengan hasil observasi ketiga ahli pada Tabel.

Tabel 4. Data Hasil Observasi Ahli Uji Coba Terbatas (Skala Kecil)

\begin{tabular}{cccccccccccc}
\hline $\begin{array}{c}\text { Kod } \\
\text { e }\end{array}$ & $\mathbf{1}$ & $\mathbf{2}$ & $\mathbf{3}$ & $\mathbf{4}$ & $\mathbf{5}$ & $\mathbf{6}$ & $\mathbf{7}$ & $\mathbf{8}$ & $\mathbf{9}$ & $\mathbf{1}$ & $\mathbf{J M}$ \\
Ahli & \multicolumn{8}{c}{ Hasil Penilaian Ahli } \\
& \multicolumn{8}{c}{ (Lembar Observasi) } \\
\hline A1 & 5 & 5 & 5 & 4 & 3 & 4 & 3 & 4 & 5 & 4 & \\
A2 & 5 & 5 & 5 & 4 & 4 & 4 & 2 & 4 & 5 & 4 & 42 \\
A3 & 5 & 5 & 5 & 3 & 3 & 4 & 2 & 4 & 5 & 4 & 40 \\
\hline
\end{tabular}

Keterangan:

A1 : Ahli 1 (Dosen)

A2 : Ahli 2 (Pengawas PJOK)

A3 : Ahli 3 (Guru PJOK) 
Berdasarkan norma nilai observasi para ahlipada Tabel. kategorisasi, distribusi frekuensi 5.

Tabel 5. Distribusi Frekuensi Penilaian Kesesuaian Ahli Produk Awal

\begin{tabular}{ccccc}
\hline Kategori & $\begin{array}{c}\text { Kurang } \\
\text { Sesuai }\end{array}$ & $\begin{array}{c}\text { Cukup } \\
\text { Sesuai }\end{array}$ & Sesuai & Jumlah \\
\hline $\mathrm{F}$ & 0 & 0 & 3 & 3 \\
$\%$ & 0 & 0 & $100 \%$ & $100 \%$ \\
\hline
\end{tabular}

Berdasarkan Tabel. 5, ketiga ahli memberikan nilai observasi kelayakan penggunaan produk awal dengan rata-rata $(41,3)$ dan berada pada interval $(37 \leq X) k$ ategori (sesuai), sehingga ketiga ahli (100\%) menilai bahwa produk awal pengembangan berupamodel latihan Sirkuit Pasing Bawah T-Desain (SPBT-Desain) bola voli "Baik danLAYAK"untuk dilanjutkanke tahap uji coba kelayakan penggunaan produk awalpada uji coba lapangan utama (skala besar), dengan beberapa saran perbaikan.

3. Hasil uji coba lapangan utama (skala besar) penggunaan produk awal

Setelah produk awal melalui tahap uji coba terbatas (skala kecil), dilanjutkan dengan uji coba lapangan utama (skala besar) penggunaan produk awal, dengan melibatkan 1 kelas pada 3 sekolah menengah pertama dan 1 kelas pada 3 sekolah menengah atas, dengan hasil observasi ketiga ahli pada Tabel.

6.

Tabel 6. Data Hasil Observasi Ahli Uji Coba Lapangan Utama (Skala Besar)

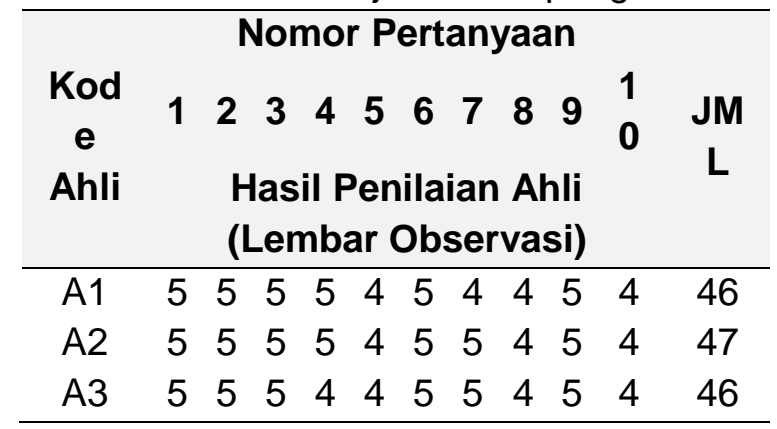

Keterangan:

A1 : Ahli 1 (Dosen)

A2 : Ahli 2 (Pengawas PJOK)

A3 : Ahli 3 (Guru PJOK)

Berdasarkan norma kategorisasi, distribusi frekuensi nilai observasi para ahli pada Tabel. 7. 
Tabel 7. Distribusi Frekuensi Penilaian Kesesuaian Ahli Produk Awal

\begin{tabular}{ccccc}
\hline Kategori & $\begin{array}{c}\text { Kurang } \\
\text { Sesuai }\end{array}$ & $\begin{array}{c}\text { Cukup } \\
\text { Sesuai }\end{array}$ & Sesuai & Jumlah \\
\hline $\mathrm{F}$ & 0 & 0 & 3 & 3 \\
$\%$ & 0 & 0 & $100 \%$ & $100 \%$ \\
\hline
\end{tabular}

Berdasarkan Tabel. 7, ketiga ahli memberikan nilai observasi kelayakan penggunaan produk awal dengan rata-rata $(46,3)$ dan berada pada interval $(37 \leq \mathrm{X})$ kategori (sesuai), sehingga ketiga ahli (100\%) menilai bahwaproduk awal pengembangan berupamodel latihan Sirkuit Pasing Bawah T-Desain (SPBT-Desain) bola voli, siap disempurnakan sesuai dengan beberapa saran perbaikan untuk dijadikan produk akhir pengembangan yang"Baik danLayak" digunakan sebagai bentuk aktivitas belajar siswa dalam pembelajaran PJOK untuk tingkat sekolah menengah.

\section{Produk Akhir Pengembangan}

Setelah melalui tiga tahap uji coba produk, dengan penyempurnaan sesuai masukan dan saran para ahli, makaproduk akhir pengembangan secara umum dapat diuraikan sebagai berikut.

1. Pengantar Produk

Pengembangan.

Sirkuit Pasing Bawah T-Desain atau disingkat SPBT-Desain ini merupakan sebuah model latihan pasing bawah yang dikembangkan menggunakan unsur latihan sirkuit yang didesain untuk menerapkan bentuk-bentuk latihan pasing bawah bola voli.

SPBT-Desain dirangkai dalam 5 pos latihan yang dilakukan secara kontinyu dan 3 pos latihan yang dilakukan dalam bentuk game atau permainan pasing bawah bola voli, sehingga bentuk sirkuit dalam model ini menggunakan 8 pos latihan yang memiliki bentuk, ketentuan dan level latihan yang berbeda-beda.

2. Tujuan Model Latihan

Tujuan dari model latihan yang dikembangkan ini, adalah:

a) Model desain latihan digunakan sebagai variasi aktivitas belajar siswa pada kegiatan inti pembelajaran PJOK pada tingkat sekolah menengah.

b) Model desain latihan dapat digunakan sebagai salah satu program latihan pasing bawah bola voli pada kegiatan ekstrakurikuler atau klub bola voli.

3. Ketentuan Latihan

Dalam pelaksanaan model latihan SPBT-Desain ini, ada beberapa hal yang perlu diperhatikan, yaitu:

a) Model latihan ini dikhususkan untuk aktivitas belajar siswa, sehingga dilakukan setelah kegiatan pembukaan termasuk aktivitas pemanasan.

b) Ditekankan kepada siswa untuk selalu berusaha melakukan semua aktivitas latihan dari pos 1 sampai pos 8 dengan teknik 
dasar pasing bawah yang baik dan benar.

c) Penekanan latihan ada pada beberapa hal penting, yaitu

a. (sikap awal); kedua kaki dibuka selebar bahu, kedua lutut ditekuk rendah, badan sedikit dicondongkan ke depan, kedua tangan lurus disatukan dengan teknik genggaman jari, kedua mata memperhatikan arah datangnya bola, dan selalu menempatkan badan sejajar dengan bola.

b. (saat pelaksanaan); mengayunkan kedua lengan tangan sejajar ke arah datangnya bola sebelum bola terlebih dahulu bersentuhan dengan tangan, pada saat mengayunkan tangan kedua siku tangan tidak ditekukan, ayunan tangan terus lurus sampai sejajar dengan dagu, perkenaan bola tepat seimbang antara kedua lengan tangan dengan poros ayunan kedua lengan pada kedua bahu.

d) Pada saat pelaksanaan diusahakan guru selalu mendampingi siswa untuk memberikan arahan pelaksanaan latihan.

\section{Bentuk Latihan}

Bentuk latihan terdiri dari 8 pos, dengan pembagian pos latihan adalah:

5 (lima) pos latihan yang dilakukan secara kontinyu, terdiri dari:

a) Pos 1; Latihan Pasing Bawah Bola Diam. b) Pos 2; Latihan Menangkap Bola Bentuk Pasing Bawah.

c) Pos 3; Latihan Pasing Bawah Bola Dipantulkan.

d) Pos 4; Latihan Pasing Bawah 1 Arah Bola Dilambungkan.

e) Pos 5; Latihan Pasing Bawah 3 Arah Bola Dilambungkan.

3 (tiga) pos latihan yang dilakukan dalam bentuk game dan permainan, terdiri dari:

a) Pos 6; Latihan Pasing Bawah 1 Arah Berpasangan.

b) Pos 7; Latihan Pasing Bawah 3 Arah Berkelompok

c) Pos 8; Game Pasing Bawah 6 vs 6 .

Untuk penjelasan dari masingmasing pos latian, dapat dilihat pada: "Buku PanduanModel Latihan Sirkuit Pasing Bawah TDesain (SPBT-Desain) Bola Voli"yang dilengkapi dengan Video Aktivitas Latihan pada masingmasing Pos Latihan sebagai Produk Akhir Penelitian dan Pengembangan.

\section{SIMPULAN DAN SARAN}

Simpulan dari hasil penelitian dan pengembangan ini, secara umum adalah: (1) Produk akhir pengembangan disusun dalam sebuah buku pedoman yang dilengkapi dengan video aktivitas latihan dan diberi judul: "Buku Panduan Model Latihan Sirkuit Pasing Bawah T-Desain (SPBTDesain) Bola Volr', (2) Model latihan Sirkuit Pasing Bawah TDesain (SPBT-Desain) Bola Voli ini dirangkai dalam 5 pos latihan yang dilakukan secara kontinyu dan 3 
pos latihan yang dilakukan dalam bentuk game atau permainan pasing bawah bola voli, sehingga bentuk sirkuit dalam model ini menggunakan 8 pos latihan yang memiliki bentuk, ketentuan dan level latihan yang berbeda-beda, dan (3) Model latihan Sirkuit Pasing Bawah T-Desain (SPBTDesain) Bola Voli ini "Baik dan Layak" digunakan sebagai bentuk aktivitas belajar siswa dalam pembelajaran PJOK untuk tingkat sekolah menengah.

Berdasarkan simpulan dari temuan dalam penelitian dan pengembangan ini, peneliti menyarankan kepada mahasiswa PJKR dan para guru PJOK untuk dapat menggunakan model pengembangan ini sebagai salah satu alternatif aktivitas belajar siswa pada materi pasing bawah bola voli, karena berdasarkan hasil uji coba produk diketahui beberapa keunggulan dari produk pengembangan, yaitu: (1) model latihan memiliki variasi latihan yang beragam dan berbeda-beda sehingga aktivitas belajar siswa akan lebih bevariasi dan menarik, (2) model latihan memungkinkan siswa untuk belajar secara bertahap dari aktivitas yang mudah sampai aktivitas yang kompleks, karena latihan dilakukan secara bagian per bagian keterampilan teknik dasar pasing bawah, (3) model latihan memungkinkan keterlibatan banyak siswa dalam melakukan aktivitas belajar baik sebagai pemegang bola dan pelaksana latihan, (4) model pengembangan tidak hanya dapat melatih keterampilan dasar pasing bawah bola voli, tetapi aktivitas latihan juga dapat melatih feeling ball siswa, penempatan posisi badan yang baik, keakuratan hasil pasingan, kebugaran jasmani siswa, (5) model latihan dapat mengatasi kekurangan sarana belajar seperti bola voli dan (6) siswa dapat belajar bertanggung jawab dan saling bekerjasama dalam melakukan aktivitas belajar secara bersama dan meningkatkan keterampilan rekan sebagai anggota regu dan tim.

\section{DAFTAR PUSTAKA}

Depdiknas, (2006). Peraturan Mentri Pendidikan Nasional Republik Indonesia No 23 tahun 2006 Tentang Standar Kompetensi Lulusan Untuk Satuan Pendidikan Dasar dan Menengah. Jakarta BSNP.

Fédération Internationale de Volleyball (FIVB), (2016). Official Volleyball Rules 20172020 - Approved by the 35th FIVB Congress 2016. FIVB.

Klika, Brett \& Jordan, Chris (2013). High-Intensity Circuit Training Using Body Weight: Maximum Results With Minimal Investment. ACSM's Health \& Fitness Journal.

Lenberg, K (2016). Volleyball Skills \& Drills, American Volleyball Coaches Association. United States: Human Kinetics.

Lehnert, $\quad M, \quad$ Stastny, $P, \ldots$ etc (2015). The effect of combined machine and body weight circuit training for women on 
muscle strength and body composition.Journal Physical Education and Sport.

M. Sajoto. (1995). Peningkatan dan Pembinaan Kekuatan Kondisi Fisik Dalam Olahraga. Semarang: Dahara Prize.

Permendikbud (2016), No 21 Tahun 2016; Tentang Standar Isi Pendidikan Dasar dan Menengah. Indonesia.

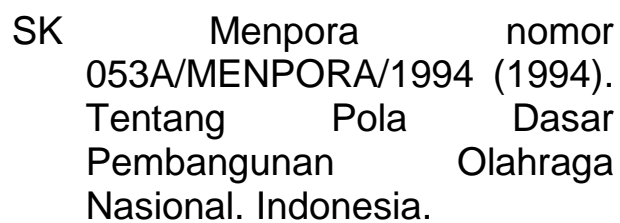

Sugiyono, (2010). Metode Penelitian Kuantitatif, Kualitatif dan R\&D, Bandung: Alfabeta.

Tapo, Y, B, O (2017). Pengembangan Model Latihan Olahraga Pernapasan Untuk Pemeliharaan Kesehatan Kardiorespirasi. (S2 thesis, UNY), eprints@uny:https://eprints.uny .ac.id/53317/

Undang-Undang RI (2003), Nomor 20 Tahun 2003; Tentang Sistem Pendidikan Nasional. Indonesia. 